\title{
Glutathione Synthesis in Human Erythrocytes
}

\section{PURIFICATION AND PROPERTIES OF THE ENZYMES OF GLUTATHIONE BIOSYNTHESIS}

\author{
Phimip W. Majerus, M. J. Brauner, M. B. Smith, and \\ Virginia MinNich \\ From the Departments of Internal Medicine and Biochemistry, Washington \\ University School of Medicine, St. Louis, Missouri 63110
}

A в S T RA C T The two enzymes required to synthesize glutathione de novo have been purified from human erythrocytes. Glutamylcysteine synthetase was purified 4300 -fold and was approximately $80 \%$ pure based on polyacrylamide gel electrophoresis. The purified enzyme catalyzes the formation of $30.5 \mu$ moles of $\gamma$-glutamylcysteine per $\mathrm{mg}$ of protein per $\mathrm{hr}$ and is inhibited by sulfhydryl inhibitors.

Glutathione synthetase was purified 6000-fold from erythrocytes to homogeneity as determined by polyacrylamide gel electrophoresis. The erythrocyte enzyme has a molecular weight of 150,000 and catalyzes the formation of $35.9 \mu$ moles of glutathione per $\mathrm{mg}$ of protein per hr. Comparison of the amino acid composition and some kinetic parameters of yeast glutathione synthetase and the erythrocyte enzyme demonstrate similarities between these enzymes.

\section{INTRODUCTION}

The two enzymes required to synthetize glutathione were described by Bloch and Snoke in extracts from yeast and pigeon liver (1-3). These workers purified glutathione (GSH) synthetase ${ }^{1}$ from yeast (2) and partially purified glutamylcysteine (GC) synthetase from hog liver (3) and studied the mechanisms of these reactions. In more recent studies by $\mathrm{Mooz}$ and Meister (4), the yeast GSH synthetase has been purified to homogeneity, and the reaction mechanism and properties

This work was presented in part at the meeting of the American Society of Clinical Investigation, Atlantic City, N. J., May, 1970 (1970. J. Clin. Invest. 49: 60a.).

Dr. Majerus is a Teaching and Research Scholar of the American College of Physicians.

Received for publication 21 January 1971 and in revised form 31 March 1971.

1 Abbreviations used in this paper: ANS, analine naptholsulfonic acid; GC, glutamylcysteine; GSH, glutathione, reduced. of this enzyme have been further elucidated. We have recently described these enzymes in hemolysates of human erythrocytes (5-7) and now report the purification and properties of the erythrocyte enzymes. GC synthetase has been purified 4300-fold from erythrocyte hemolysates. The most highly purified preparations contain several bands on polyacrylamide disc gel electrophoresis with the major band being identified as GC synthetase. GSH synthetase has been purified 6000 -fold to homogeneity from erythrocyte extracts as determined by polyacrylamide disc gel electrophoresis and analytical ultracentrifugation.

\section{METHODS}

GC synthetase was assayed by measurement of the incorporation of glutamic acid- ${ }^{8} \mathrm{H}$ into GC in the presence of ATP, $\mathrm{Mg}^{++}$, and cysteine (7). GSH synthetase was assayed by measurement of the incorporation of glycine $-{ }^{14} \mathrm{C}$ into $\mathrm{GSH}$ in the presence of GC, ATP, and $\mathrm{Mg}^{++}$(7). GC and GSH were isolated from the respective reaction mixtures as their insoluble cadmium mercaptides (7). Assays were carried out at $37^{\circ} \mathrm{C}$. One unit of enzyme activity is defined as $1 \mu$ mole of product formed per hr. All substrates were obtained or prepared as described previously (7). The DEAE-cellulose used was Whatman DE23. Protein concentration was determined by the method of Lowry, Rosebrough, Farr, and Randall (8). Disc gel electrophoresis was performed on $5 \%$ polyacrylamide gels (9). Gels were stained with Coomassie blue, or alternatively when active enzyme was to be eluted from gels, bands were visualized with $0.004 \%$ analine naptholsulfonic acid (ANS) (10).

Purification of GC synthetase. Extracts of erythrocytes from $80 \mathrm{U}$ of outdated bank blood were used in the purification of the enzymes of glutathione synthesis. The initial steps of purification were carried out in batches of approximately $1000 \mathrm{ml}$ of packed erythrocytes, and all procedures were performed at $4^{\circ} \mathrm{C}$. Erythrocytes were sedimented from ACD plasma by centrifugation for $10 \mathrm{~min}$ at $6000 \mathrm{~g}$. After the cells were washed twice in $0.15 \mathrm{~m}$ sodium chloride, they were hemolyzed by addition of 10 volumes of cold distilled water. Stroma was removed by centrifugation at $23,000 \mathrm{~g}$ for $10 \mathrm{~min}$. 


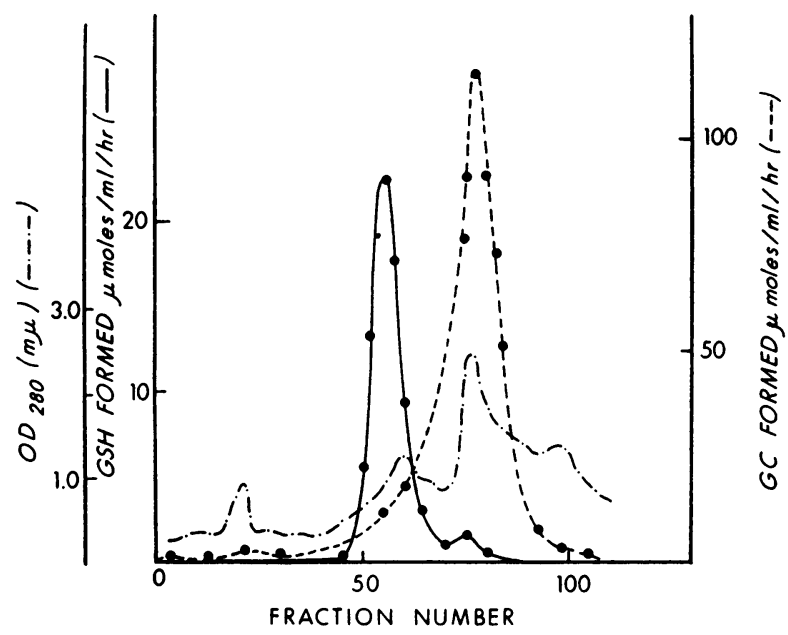

FIgURE 1 DEAE Sephadex chromatography of the enzymes of GSH synthesis. (See Methods for details.) - - $\mathrm{GSH}$ synthetase; - - - - - $\bullet$ GC synthetase.

Removal of hemoglobin. Whatman DEAE 23 was initially suspended in $1 \mathrm{M} \mathrm{K} \mathrm{K}_{2} \mathrm{HPO}_{4}$ (40 g DEAE/liter) and stirred for $1 \mathrm{hr}$. The DEAE was then collected on a Buchner funnel, and this procedure was repeated twice. The DEAE was next washed on the funnel with water until the filtrate was neutral and then resuspended in $\mathrm{H}_{2} \mathrm{O}$ at a concentration of $8 \mathrm{~g} / 100 \mathrm{ml}$, and the $\mathrm{pH}$ was adjusted to 7.0 with $\mathrm{HCl}$ or $\mathrm{NaOH}$ as necessary. This DEAE suspension was added to stroma-free hemolysate $(1 \mathrm{~g} \mathrm{DEAE} / 2 \mathrm{~g}$ $\mathrm{Hb})$, and the mixture was stirred for $40 \mathrm{~min}$. The DEAE was then collected on a Buchner funnel and washed with $0.003 \mathrm{M}$ potassium phosphate $\mathrm{pH} 7.0$ until the filtrate was colorless. The DEAE was then resuspended in $0.3 \mathrm{M}$ potassium chloride also containing $0.003 \mathrm{M}$ potassium phosphate $\mathrm{pH} 7.0$ ( $2 \mathrm{ml}$ of $\mathrm{KCl}$ solution per $/ \mathrm{ml}$ original packed erythrocytes). After stirring for $40 \mathrm{~min}$, the eluate which contained both GSH and GC synthetase was collected by filtration.

First ammonium sulfate step. The DEAE eluate from the previous step was adjusted to contain $0.1 \mathrm{M}$ potassium phosphate $\mathrm{pH} 7.0$ (using $1 \mathrm{M}$ potassium phosphate), and solid ammonium sulfate $(25.8 \mathrm{~g} / 100 \mathrm{ml})$ was added slowly with stirring. After stirring for $15 \mathrm{~min}$, the suspension was allowed to settle for $30 \mathrm{~min}$. The solution was then centrifuged at $23,000 \mathrm{~g}$ for $10 \mathrm{~min}$, and the precipitate was discarded. Solid ammonium sulfate $(19 \mathrm{~g} / 100 \mathrm{ml})$ was then added to the supernatant, and the suspension was stirred and allowed to settle as described above. The precipitate of this fraction contained both GSH and GC synthetase. The precipitate was collected by centrifugation and was stored at $4^{\circ} \mathrm{C}$ until the entire $80 \mathrm{U}$ of erythrocytes were processed. Both enzymes were stable when stored in this manner.

$D E A E$-cellulose column chromatography. The ammonium sulfate pellets from the previous step were dissolved in a minimal volume of $0.02 \mathrm{M}$ potassium phosphate $\mathrm{pH} 7.0$ and dialyzed overnight against 20 liters of $0.02 \mathrm{M}$ potassium phosphate, $\mathrm{pH} 7.0$, which contained $0.1 \mathrm{M}$ potassium chloride and $0.01 \mathrm{M} 2$-mercaptoethanol. The resulting solution (1140 $\mathrm{ml})$ was then poured over a $6 \times 115 \mathrm{~cm}$ column of DEAEcellulose previously equilibrated with this same buffer which contained $0.1 \mathrm{M}$ potassium chloride and $0.1 \mathrm{M} 2$-mercaptoethanol. After washing the column with 5 liters of this buffer, the column was eluted with a 40 liter linear gradient of $\mathrm{KCl}(0.1 \rightarrow 0.45 \mathrm{~mole} /$ liter contained in the same buffer, and $20-\mathrm{ml}$ fractions were collected. The GSH and GC synthetase were eluted between conductivities of 10 and 15 mmho $\left(4^{\circ} \mathrm{C}\right)$. The peak of $\mathrm{GSH}$ synthetase was eluted slightly before GC synthetase, but the two were not effectively separated and thus were pooled together. The pooled fractions were concentrated by ultrafiltration to a volume of $200 \mathrm{ml}$ in an Amicon concentrator using a UM-1 filter. This solution was then dialyzed overnight against 20 liters of $0.02 \mathrm{M}$ potassium phosphate, $\mathrm{pH} 7.0$, which contained $0.15 \mathrm{M}$ potassium chloride and $0.01 \mathrm{M}$ 2-mercaptoethanol.

$D E A E$ Sephadex chromatography. The enzyme solution was then poured over a $4 \times 40 \mathrm{~cm}$ column of DEAE Sephadex (A-50) previously equilibrated with the same buffer. The column was washed with $500 \mathrm{ml}$ of the equilibrating buffer and was then eluted with $4200 \mathrm{ml}$ of buffer in a linear gradient from 0.15 to $0.35 \mathrm{~m}$ potassium chloride, and $20-\mathrm{ml}$ fractions were collected. GSH synthetase was eluted before GC synthetase (Fig. 1), and the fractions containing each were pooled separately and concentrated as described above. The GC synthetase solution was concentrated to 15 $\mathrm{ml}$.

Sephadex G-150 chromatography. $6 \mathrm{ml}$ of the resulting GC synthetase solution was then added to a $2.5 \times 100 \mathrm{~cm}$ column of Sephadex G-150 and eluted with 0.05 M potas-

TABLE I

Purification of Glutamylcysteine Synthetase

\begin{tabular}{|c|c|c|c|c|}
\hline Step & $\begin{array}{l}\text { Total } \\
\text { protein }\end{array}$ & $\begin{array}{c}\text { Total } \\
\text { activity }\end{array}$ & $\begin{array}{l}\text { Specific } \\
\text { activity }\end{array}$ & $\begin{array}{l}\text { Fold } \\
\text { purified }\end{array}$ \\
\hline & $g$ & Units & $\begin{array}{c}\text { Units/ } \\
m g\end{array}$ & \\
\hline 1. Hemolysate & 5000 & 35,000 & 0.007 & - \\
\hline 2. Batch DEAE-cellulose, $45-75 \%$ ammonium sulfate & 105.7 & 23,800 & 0.225 & 32 \\
\hline 3. DEAE-cellulose column & 5.86 & 16,800 & 2.87 & 410 \\
\hline 4. DEAE Sephadex column & 1.1 & 9,280 & 8.44 & 1205 \\
\hline 5. Sephadex G-150 column & 0.675 & 8,900 & 13.1 & 1870 \\
\hline 6. $50-60 \%$ ammonium sulfate & 0.131 & 4,000 & 30.5 & 4350 \\
\hline
\end{tabular}

Assays used in the purification of GC synthetase were performed as described previously (7) except that 15-min incubations were used and potassium phosphate $\mathrm{pH} 7.0$ was used as buffer. We subsequently discovered that the results using phosphate buffer are 1.5- to 2.0-fold lower than those obtained with imidazole buffer. 
TABLE II

Purification of GSH Synthetase

\begin{tabular}{lcccc}
\hline \multicolumn{1}{c}{ Step } & $\begin{array}{c}\text { Total } \\
\text { protein }\end{array}$ & $\begin{array}{c}\text { Total } \\
\text { activity }\end{array}$ & $\begin{array}{c}\text { Specific } \\
\text { activity }\end{array}$ & $\begin{array}{c}\text { Fold } \\
\text { purified }\end{array}$ \\
\hline & $g$ & Units & $\begin{array}{c}\text { Units } / \\
m g\end{array}$ & - \\
1. Hemolysate & 5000 & 30,000 & 0.006 & 44 \\
2. Batch DEAE-cellulose, 45-75\% ammonium sulfate & 105.7 & 27,000 & 0.256 & 730 \\
3. DEAE-cellulose column & 5.86 & 25,700 & 4.4 & 1610 \\
4. DEAE Sephadex column & 0.91 & 8,900 & 9.7 & 3950 \\
5. 45.55\% ammonium sulfate & 0.35 & 8,300 & 23.7 & 4880 \\
6. Sephadex G-150 column & 0.12 & 3,520 & 29.3 & 6000 \\
7. Heat 50 C for 60 min & 0.085 & 3,050 & 35.9 & 6 \\
\hline
\end{tabular}

GSH synthetase was assayed as described previously (7).

sium phosphate, $\mathrm{pH}$ 7.0, which contained $0.001 \mathrm{M}$ dithiothreitol and in some cases $0.001 \mathrm{M}$ ATP. (ATP was added because it seemed to stabilize the enzyme slightly at this stage of purification.) This column step was repeated using an additional $6 \mathrm{ml}$ of enzyme solution, and the fractions containing GC synthetase from both columns were pooled and concentrated by ultrafiltration to a volume of $20 \mathrm{ml}$.

Second ammonium sulfate step. The GC synthetase solution was then adjusted to $0.1 \mathrm{M}$ potassium phosphate, $\mathrm{pH}$ 7.0 , and solid ammonium sulfate $(25.8 \mathrm{~g} / 100 \mathrm{cc})$ was added with stirring. After stirring $20 \mathrm{~min}$, the suspension was allowed to settle for $20 \mathrm{~min}$. After centrifugation at $50,000 \mathrm{~g}$ for $10 \mathrm{~min}$, the precipitate was discarded, and ammonium sulfate $(2.9 \mathrm{~g} / 100 \mathrm{ml})$ was added to the supernatant solution. This suspension was again stirred and allowed to settle as described above, and after centrifugation the precipitate was discarded. Solid ammonium sulfate $(6 \mathrm{~g} / 100 \mathrm{ml})$ was added to the supernatant solution, and after stirring and settling, the resulting precipitate was collected and then dissolved in a minimal volume of $0.05 \mathrm{M}$ potassium phosphate, $\mathrm{pH} 7.0$, which contained $0.001 \mathrm{~m}$ dithiothreitol. The results of the purification are shown in Table I. The purified enzyme was stored frozen at $-120^{\circ} \mathrm{C}$ and was stable for at least several months under these conditions. The purified enzyme was relatively unstable when stored at $4^{\circ} \mathrm{C}$ and lost $50 \%$ of its activity in $1 \mathrm{wk}$ when stored in dilute solution.

Purification of GSH synthetase. GSH synthetase was purified along with GC synthetase until the DEAE Sephadex column step where the two enzymes were separated. The pooled fractions from this column containing GSH synthetase were concentrated to a volume of $100 \mathrm{ml}$.

Second ammonium sulfate step. The GSH synthetase solution was adjusted to $0.1 \mathrm{~m}$ potassium phosphate, $\mathrm{pH} 7.0$, which contained $0.001 \mathrm{M}$ dithiothreitol, and ammonium sulfate $(25.8 \mathrm{~g} / 100 \mathrm{ml})$ was added with stirring. After mixing and centrifugation as described above, the precipitate was discarded, and ammonium sulfate $(5.9 \mathrm{~g} / 100 \mathrm{ml})$ was added to the supernatant solution. The resulting precipitate was dissolved in a minimal volume $0.03 \mathrm{~m}$ potassium phosphate, $\mathrm{pH} 7.0$, which contained $0.001 \mathrm{M}$ dithiothreitol and $0.001 \mathrm{M}$ ATP.

Sephadex G-150 chromatography. The GSH synthetase solution was next poured onto a $2.5 \times 100 \mathrm{~cm}$ column of Sephadex G-150 and eluted with $0.05 \mathrm{~m}$ potassium, $\mathrm{pH} 7.0$, which contained $0.001 \mathrm{M}$ dithiothreitol. The fractions containing GSH synthetase were pooled and concentrated by ultrafiltration to a volume of $10 \mathrm{ml}$.
Heat step. The GSH synthetase from the preceding step was diluted to a concentration of $3.0 \mathrm{mg} / \mathrm{ml}$ in $0.02 \mathrm{M}$ potassium phosphate, $\mathrm{pH} 7.0$, which contained $0.005 \mathrm{M}$ dithiothreitol and $0.03 \mathrm{M}$ GSH. This solution was heated at $50^{\circ} \mathrm{C}$ for $1 \mathrm{hr}$. The resulting flocculent precipitate was discarded after centrifugation, and the supernatant solution containing GSH synthetase was concentrated to a volume of $6 \mathrm{ml}$ by ultrafiltration. The summary of the purification of GSH synthetase is shown in Table II. The final preparation was stable at $4^{\circ} \mathrm{C}$ for at least several months when stored in GSH.

Physical studies. Sedimentation constants of the purified enzymes were determined by sedimentation velocity experiments at $59,780 \mathrm{rpm}$ in a Beckman model $\mathrm{E}$ ultracentrifuge using Scheieren optics in artificial boundary cells. The diffusion constant of GSH synthetase was determined similarly at $42,040 \mathrm{rpm}$ (11). The molecular weight was calculated from these values using a partial specific volume of $0.74 \mathrm{cc} / \mathrm{g}$ which was calculated from the amino acid composition of homogeneous GSH synthetase (11). Alternatively, the molecular weight was determined by equilibrium sedimentation at $21,000 \mathrm{rpm}$ (11). The amino acid composition of $\mathrm{GSH}$ synthetase was determined, after acid hydrolysis in sealed evacuated tubes in constantly boiling $\mathrm{HCl}$ for $22 \mathrm{hr}$, on a Beckman $120 \mathrm{C}$ amino acid analyzer (12).

\section{RESULTS}

Purification of enzymes. GSH and GC synthetase were difficult to separate from each other and copurified until DEAE Sephadex chromatography (Fig. 1). At this step the two enzymes are largely resolved. Thus, the GC synthetase-containing fractions pooled from this column contained $10 \%$ of the GSH synthetase activity, and conversely, the GSH synthetase-containing fractions were contaminated with $16 \%$ of the GC synthetase eluted from this column.

GC synthetase. The final preparation of GC synthetase was purified over 4000 -fold and had a specific activity of $30.5 \mathrm{U} / \mathrm{mg}$. This preparation appeared to be homogeneous both by velocity sedimentation in the analytical ultracentrifuge and by rechromatography on DEAE Sephadex where there was correspondence between protein and enzyme activity. Despite the evidence 


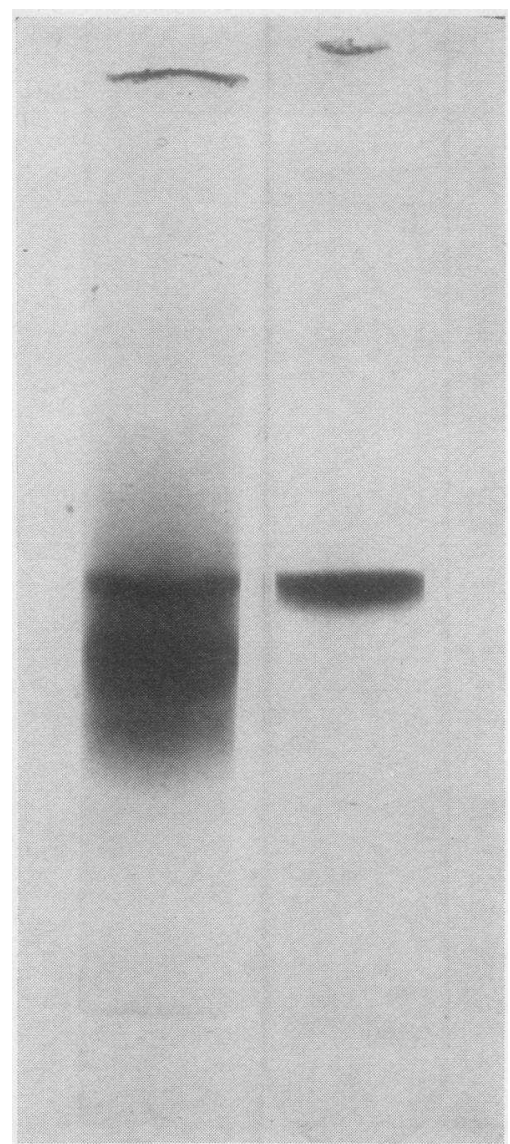

FIgUre 2 Polyacrylamide gel electrophoresis of the purified enzymes of GSH synthesis. Gel on left: $150 \mu \mathrm{g}$ GC synthetase. Gel on right: $50 \mu \mathrm{g}$ GSH synthetase. These gels were stained with Coomassie blue. The protein bands on the two gels shown cannot be directly compared for migration distance since the runs were done at different times.

of homogeneity, the preparation contained residual GSH synthetase activity. Thus, in fresh hemolysates the ratio of GC synthetase/GSH synthetase is $2.2 / 1$ while in the final preparation this ratio is $56 / 1$. This residual GSH synthetase activity could be removed by rechromatography on DEAE Sephadex, but no increase in specific activity resulted from this procedure. Disc gel electrophoresis of this preparation disclosed one major protein band and several smaller bands which comprised about $20 \%$ of the total protein as shown in Fig. 2. The protein bands were detected in an unstained gel in $0.004 \%$ ANS with ultraviolet light (10) to establish that the major protein band was GC synthetase. Each of the bands was then cut from the gel, and the protein was then eluted from the gel slices by homogenizing in 0.02 M potassium phosphate which contained $0.001 \mathrm{M}$ dithiothreitol. $87 \%$ of the GC synthetase activity eluted from the gel was contained in the major band with the remaining activity in the slices adjacent to this band on either side. We were unable to determine whether the contaminant minor bands contain the remaining enzyme activity (i.e., isozymes). Further attempts to remove the contaminants including chromatography on hydroxyapatite and cellulose phosphate were unsuccessful. The contaminating bands were not sufficiently separated from the enzyme to allow efficient separation by preparative disc gel electrophoresis.

Properties of GC synthetase. The sedimentation constant $\left(s_{20, w}\right)$ for GC synthetase was $5.4 \mathrm{~S}$ as determined by velocity sedimentation in the analytical ultracentrifuge. Since the final preparation was obviously impure, molecular weight and amino acid composition were not determined. The sedimentation constant and position of elution from Sephadex G-150 suggest that GC synthetase has approximately the same molecular weight as $\mathrm{GSH}$ synthetase. This enzyme was less stable than GSH synthetase both on storage at $4^{\circ} \mathrm{C}$ and upon heating (see below). The activity of GC synthetase with varying $\mathrm{pH}$ is shown in Fig. 3. The optimum $\mathrm{pH}$ for activity is approximately 7.5. The activity of GC synthetase with varying substrate concentrations was measured and plotted by the method of Lineweaver and Burk (13) as shown in Fig. 4. The Michaelis constants calculated from these curves for L-glutamic acid, cysteine, and ATP were $2.2 \times 10^{-3}$ moles/liter, $3 \times 10^{-4}$ moles/liter, and $4.3 \times 10^{-4} \mathrm{moles} /$ liter, respectively. The enzyme was inactive $(<1 \%)$ when $\mathrm{D}$-glutamic acid was substituted for L-glutamic acid at $10^{-2}$ moles/liter.

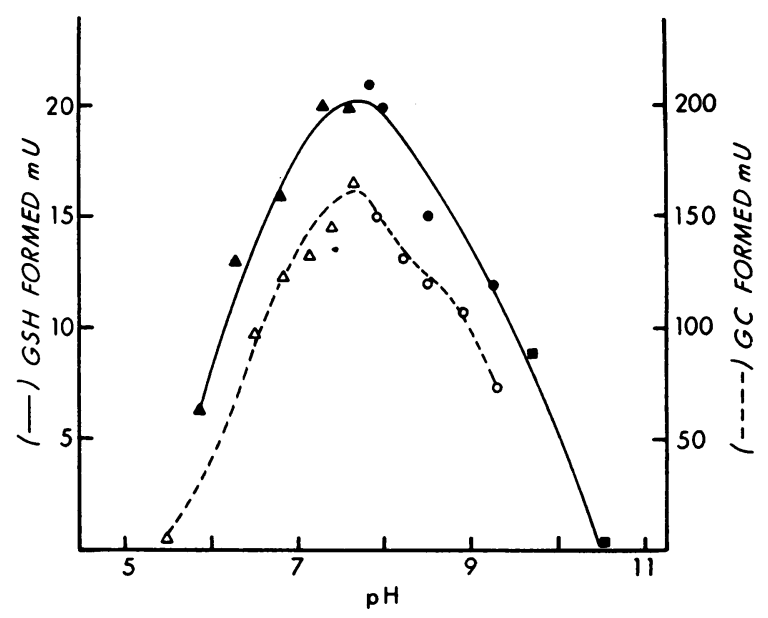

Figure 3 Effect of varying $\mathrm{pH}$ on the activity of the enzymes of GSH synthesis. Reaction mixtures were prepared at 3 times the standard volume excluding enzyme and glycine $-{ }^{14} \mathrm{C}$ or glutamic acid $-{ }^{3} \mathrm{H}$ respectively, for $\mathrm{GSH}$ and $\mathrm{GC}$ synthetase. The $\mathrm{pH}$ of the reaction mixtures were adjusted with $1 \mathrm{~m}$ imidazole or $1 \mathrm{~m}$ Tris to the desired $\mathrm{pH}$, and aliquots were then taken and used in the standard assays. $\Delta \boldsymbol{\Delta}$, Imidazole buffer; $\bullet \bigcirc$, Tris buffer; $\boldsymbol{\square}$, potassium carbonate buffer; —, GSH synthetase; - - -, GC synthetase. 
The effect of sulfhydryl inhibitors on GC synthetase is shown in Table III. Enzyme was initially treated with either iodoacetamide or $N$-ethylmaleimide, and subsequently dithiothreitol was added to destroy excess inhibitor. Sulfhydryl inhibitors could not be added directly to enzyme assay reaction mixtures since inhibition in this case could be due to reaction with the substrate cysteine. Both iodoacetamide and $N$-ethylmaleimide inhibit GC synthetase suggesting that a sulfhydryl group is essential for activity of this enzyme.

GSH synthetase. The final preparation of GSH synthetase was purified 6000 -fold and has a specific activity of $35.9 \mathrm{U} / \mathrm{mg}$. The enzyme was homogeneous by velocity sedimentation in the analytical ultracentrifuge and gave a single band on polyacrylamide gel electrophoresis (Fig. 2). The GSH synthetase preparation after the second ammonium sulfate fractionation contained residual GC synthetase with the ratio of GC to GSH synthetase being 0.09 . The residual GC synthetase was removed by heat treatment. In preliminary experiments it was determined that both GC synthetase and GSH synthetase were rapidly inactivated by heating at $60^{\circ} \mathrm{C}$. GC synthetase activity is destroyed with a $t^{\frac{1}{2}}$ of $4 \mathrm{~min}$ at $50^{\circ} \mathrm{C}$ while $\mathrm{GSH}$ synthetase activity is largely retained (Table IV). When the enzyme was heated in the presence of GSH, the enzyme was stabilized, and two-thirds of the original activity was recovered after heating $1 \mathrm{hr}$ while GC synthetase was entirely destroyed. The activity of GSH synthetase with varying $\mathrm{pH}$ strikingly parallels that for GC synthetase with a broad curve with optimum $\mathrm{pH}$ between 7 and 8 (Fig. 3). The activity of GSH synthetase at varying substrate concentrations is shown in Fig. 5 as plotted by the method of Lineweaver and Burk (13). The Michaelis constants calculated from these data for ATP, $\gamma$-glutamylcysteine, and glycine were $5 \times 10^{-4}$ moles/ liter, $2 \times 10^{-4} \mathrm{moles} / \mathrm{liter}$, and $3.6 \times 10^{-4} \mathrm{moles} / \mathrm{liter}$, re-

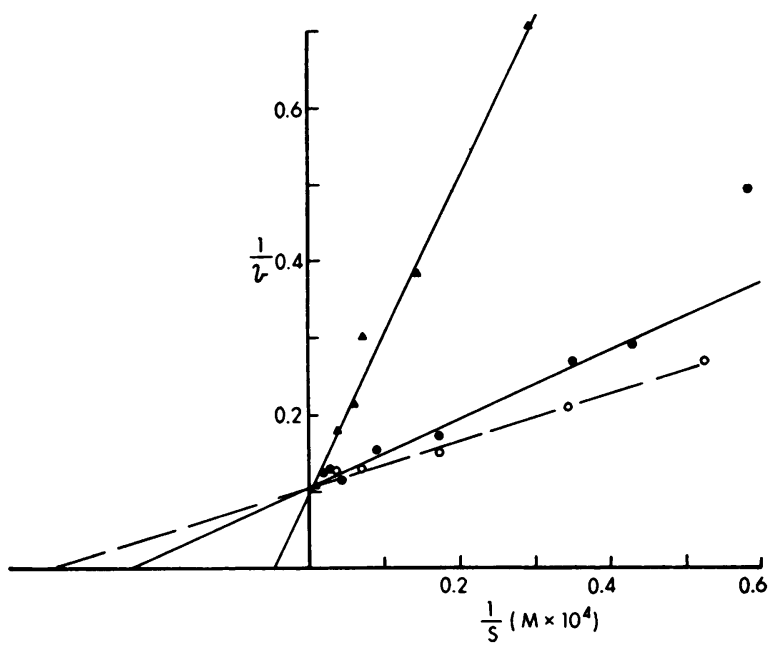

FIGURE 4 Effect of varying substrate concentrating on the activity of GC synthetase. Glutamic acid, $\mathbf{\Delta} \boldsymbol{\Delta} \mathbf{\Delta}$; cysteine, $\bigcirc \bigcirc \bigcirc ; \mathrm{ATP}, \bullet-1$ The concentrations of the unvaried substrates were as follows : $10^{-2} \mathrm{M}$ glutamic acid, $1.1 \times 10^{-2} \mathrm{M}$ cysteine, and $3.5 \times 10^{-3} \mathrm{M}$ ATP.

spectively. GSH synthetase was not inhibited by either $N$-ethylmaleimide or iodoacetamide (Table III) suggesting that the requirement for dithiothreitol in the GSH synthetase reaction serves only to maintain the substrate GC and the product GSH in a reduced state.

Physical properties of GSH synthetase. The sedimentation constant $\left(s_{20, w}\right)$ for GSH synthetase was 5.6S, and the diffusion constant $\left(d_{20, \infty}\right)$ was $3.68 \times 10^{-7} \mathrm{~cm}^{2}$ $\mathrm{sec}^{-1}$. The molecular weight calculated from these values was 148,000 . The molecular weight was also determined by equilibrium sedimentation, and a value of 152,000 was obtained. The amino acid composition of GSH synthetase is shown in Table V, and the results are expressed assuming a molecular weight of 150,000 .

TABLE III

Effect of Sulfhydryl Inhibitors on the Enzymes of Glutathione Synthesis

\begin{tabular}{lcc}
\hline \multicolumn{1}{c}{ Inhibitor } & $\begin{array}{c}\text { GC synthetase, } \\
\% \text { inhibition }\end{array}$ & $\begin{array}{c}\text { GSH synthetase, } \\
\% \text { inhibition }\end{array}$ \\
\hline Iodoacetamide, $5 \times 10^{-4}$ moles/liter & 24 & 0 \\
Iodoacetamide, $2 \times 10^{-3}$ moles/liter & 66 & 0 \\
$N$-Ethylmaleimide, $9 \times 10^{-4}$ moles/liter & 18 & 0 \\
$N$-Ethylmaleimide, $2.5 \times 10^{-3}$ moles/liter & 47 & 7 \\
\hline
\end{tabular}

GSH synthetase $(0.03 \mathrm{mg})$ was incubated with the indicated concentrations of inhibitor in $0.02 \mathrm{M}$ potassium phosphate buffer $\mathrm{pH} 7.0$ for $10 \mathrm{~min}$ at $37^{\circ} \mathrm{C}$. An excess of dithiothreitol was then added to destroy the inhibitor, and after further incubation at $37^{\circ} \mathrm{C}$ for $10 \mathrm{~min}$, aliquots were taken for enzyme assay. Experiments with glutamylcysteine synthetase were identical except that $0.04 \mathrm{mg}$ of enzyme was used. 
TABLE IV

Heat Treatment of GSH Synthetase

\begin{tabular}{lcc}
\hline & GSH synthetase & GC synthetase \\
\hline & Units $/ m l$ & Units $/ m l$ \\
Control & 69 & 6.8 \\
Heated - GSH & 21 & - \\
Heated + GSH & 50 & 0 \\
\hline
\end{tabular}

GSH synthetase, purified through the second ammonium sulfate step, was diluted to $3 \mathrm{mg}$ protein $/ \mathrm{ml}$ in $0.02 \mathrm{M}$ potassium phosphate $\mathrm{pH} 7.0$ containing $0.005 \mathrm{M}$ dithiothreitol and $0.03 \mathrm{M} \mathrm{GSH}$ where indicated. Solutions were heated at $50^{\circ} \mathrm{C}$ for $60 \mathrm{~min}$. After centrifugation to remove denatured protein, enzyme activity was measured in the supernatant solution.

\section{DISCUSSION}

GC synthetase has been previously demonstrated in several species and has been partially purified from pig heart (3) and wheat germ (15). These preparations catalyzed the formation of approximately $0.5 \mu$ mole of GC per $\mathrm{mg}$ of protein per $\mathrm{hr}$ compared with the value of 30.5 reported here for highly purified enzyme from human erythrocytes. The mechanism of $\gamma$-glutamyl peptide bond formation remains unexplained although Webster and Varner (15) suggested that a high energy glutamate complex might be involved. No such intermediate has been directly demonstrated since highly purified enzyme was not available in these early studies. The fact that GC synthetase is inhibited by sulfhydryl group inhibitors suggests that a cysteine residue may be

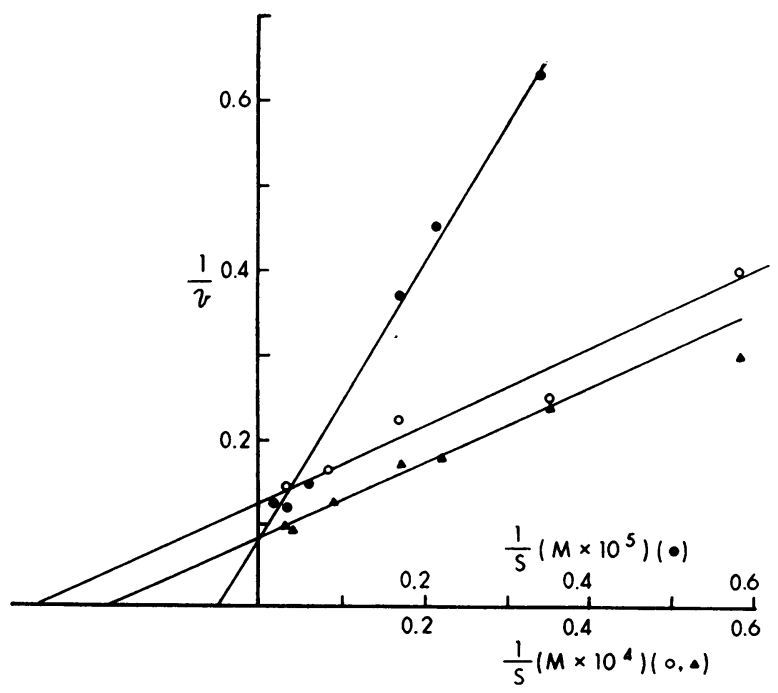

FigURE 5 Effect of varying substrate concentrations on the activity of GSH synthetase. $\boldsymbol{\gamma}$-Glutamylcysteine, $\bullet \bullet \bullet$; $\mathrm{ATP}, \boldsymbol{\Delta} \boldsymbol{\Delta} \boldsymbol{\Delta}$; glycine, $\bigcirc \bigcirc \bigcirc$. The concentrations of the unvaried substrate were as follows: $6 \times 10^{-4} \mathrm{M} \gamma$-glutamylcysteine, $3.5 \times 10^{-2} \mathrm{M}$ ATP, and $8.5 \times 10^{-3} \mathrm{M}$ glycine. important in the reaction. The Michaelis constants for glutamate and for ATP are quite similar for enzyme from wheat germ and human erythrocytes while the $\mathrm{K}_{\mathrm{m}}$ for cysteine was 10 -fold higher $\left(4 \times 10^{-3}\right.$ moles/liter $)$ in wheat germ than in erythrocytes.

GSH synthetase has been previously purified from yeast $(2,4)$ and pigeon liver (1). The homogeneous yeast enzyme is striking in that the intrinsic specific activity is 20 -fold higher than that of the erythrocyte enzyme. Despite this difference there are similarities between the yeast and erythrocyte enzymes. Thus, the molecular weight of yeast GSH synthetase is 123,000 (4) while the molecular weight of the erythrocyte enzyme determined in the present study is 150,000 . There is some similarity between the amino acid compositions of the two enzymes with essentially identical contents of isoleucine, histidine, proline, and glutamic acid. All of the remaining amino acids are present in both enzymes in amounts which agree within $20 \%$ with the exception of $\frac{1}{2}$ cystine, methionine, lysine, and arginine (4). The Michaelis constants for glycine and GC were essentially identical comparing yeast GSH synthetase with the erythocyte enzyme, while the $K_{m}$ for ATP was 3-fold higher with the latter enzyme (4).

Little is known about the regulation of GSH synthesis in erythrocytes. Since the potential for GSH synthesis far exceeds that needed to maintain normal GSH levels in erythrocytes (7), it is possible that variations

TABLE V

Amino Acid Analysis of Glutathione Synthetase

\begin{tabular}{lc}
\hline \multicolumn{1}{c}{ Amino acid } & Residues/mole* \\
\hline Lysine & 73 \\
Histidine & 27 \\
Arginine & 72 \\
Aspartic acid & 112 \\
Threonine & 64 \\
Serine & 109 \\
Glutamic acid & 160 \\
Proline & 59 \\
Glycine & 116 \\
Alinine & 135 \\
1 Cystineł & 42 \\
Valine & 98 \\
Methionine & 33 \\
Isoleucine & 61 \\
Leucine & 152 \\
Tyrosine & 30 \\
Phenylalanine & 53
\end{tabular}

Samples were hydrolyzed and analyzed as described in Methods. Tryptophane content was not measured.

* Assuming that 1 mole of GSH synthetase $=150,000 \mathrm{~g}$. $\ddagger$ Measured as cysteic acid after performic acid oxidation (14) of protein samples before acid hydrolysis. 
in the in vivo activity of these enzymes may be important in defending erythrocytes against oxidative stress. The factors which may modulate the activity of these enzymes in vivo include levels of either GSH, GSSG, NADP, NADPH, or of the respective substrates. A further factor which may be important in determining enzyme activity is the potential association of these enzymes to form a multienzyme complex. The difficulty in separating the two enzymes suggests a possible association between these enzymes. In some experiments the two enzymes did not separate on DEAE Sephadex further indicating an association between these enzymes. The factors which determine such association remain to be elucidated.

After this work was submitted for publication, a report by Orlowski and Meister (16) appeared on the purification and properties of GC synthetase from rat kidney. It is interesting that the properties of the rat kidney enzyme are very similar to those of human erythrocyte GC synthetase with respect to stability, sedimentation constant, substrate affinities, and inhibition by sulfhydryl poisons. The specific activity of the kidney enzyme was reported to be 10 -fold higher than erythrocyte enzyme although the great difference in assay techniques used makes direct comparison of specific activities difficult. These workers report that the high concentration of $\boldsymbol{\gamma}$-glutamyl cyclotransferase (an enzyme which metabolizes GC to cysteine and pyrrolidone carboxylic acid) makes direct assay of GC synthetase in kidney homogenates difficult. We performed the following experiment to exclude the possibility that $\gamma$-glutamyl cyclotransferase in erythrocytes metabolizes GC, thus causing an underestimation of GC synthetase in crude hemolysates. GC, tritium-labeled in the glutamyl moiety, $\left(2 \times 10^{-4}\right.$ moles/liter $)$ was incubated with erythrocyte hemolysate under conditions of the GC synthetase assay using unlabeled glutamic acid. After $60 \mathrm{~min}$ incubation at $37^{\circ} \mathrm{C}, 94 \%$ of the original labeled GC was isolated as its cadmium mercaptide indicating that there is no significant degradation of GC under these conditions. A similar result was obtained when ATP was omitted from reaction mixtures so that no unlabeled GC could be formed during the incubation. The amount of GC added in these experiments was equivalent to that formed after $60 \mathrm{~min}$ incubation in a standard assay. Thus, it appears that there is no significant $\gamma$-glutamyl cyclotransferase activity in erythrocytes under these conditions.

\section{ACKNOWLEDGMENTS}

The authors wish to thank Carmelita Lowry for performing the analytical ultracentrifugation studies.

This investigation was supported in part by grants from the U. S. Public Health Service, AM 10550, HE 00022, and from the American Cancer Society, PRA 33.

\section{REFERENCES}

1. Snoke, J. E., S. Yanari, and K. Bloch. 1953. Synthesis of glutathione from $\gamma$-glutamylcysteine. J. Biol. Chem. 201: 573.

2. Snoke, J. E. 1955. Isolation and properties of yeast glutathione synthetase. J. Biol. Chem. 213: 813.

3. Mandeles, S., and K. Bloch. 1955. Enzymatic synthesis of $\gamma$-glutamylcysteine. J. Biol. Chem. 214: 639.

4. Mooz, E. D., and A. Meister. 1967. Tripeptide (glutathione) synthetase. Purification, properties, and mechanism of action. Biochemistry. 6: 1722.

5. Majerus, P. W., V. Minnich, and D. Mohler. 1970. De novo biosynthesis of glutathione in extracts from human erythrocytes. J. Clin. Invest. 49: 60a.

6. Mohler, D. N., P. W. Majerus, V. Minnich, C. E. Hess, and M. D. Garrick. 1970. Glutathione synthetase deficiency as a cause of hereditary hemolytic disease. N. Engl. J. Med. 283: 1253.

7. Minnich, V., M. B. Smith, M. J. Brauner, and P. W. Majerus. 1971. Glutathione biosynthesis in human erythrocytes. I. Identification of the enzymes of glutathione synthesis in hemolysates. J. Clin. Invest. 50: 507.

8. Lowry, O. H., N. J. Rosebrough, A. L. Farr, and R. J. Randall. 1951. Protein measurement with the folin phenol reagent. J. Biol. Chem. 193: 265.

9. Davis, B. J. 1964. Disc electrophoresis. II. Method and application to human serum proteins. Ann. N. Y. Acad. Sci. 121: 404.

10. Hartman, B. K., and S. Udenfriend. 1969. A method for immediate visualization of proteins in acrylamide gels and its use for preparation of antibodies to enzymes. Anal. Biochem. 30: 391.

11. Schachman, H. K. 1957. Ultracentrifugation, diffusion, and viscometry. In Methods in Enzymology. S. P. Colowick and N. O. Kaplan, editors. Academic Press, Inc., New York. $4: 32$.

12. Spackman, D. H., W. H. Stein, and S. Moore. 1958. Automatic recording apparatus for use in the chromatography of amino acids. Anal. Chem. 30: 1190.

13. Lineweaver, H., and D. Burk. 1934. The determination of enzyme dissociation constants. J. Amer. Chem. Soc. 56: 658 .

14. Hirs, C. H. W. 1956. The oxidation of ribonuclease with performic acid. J. Biol. Chem. 219: 611.

15. Webster, G. C., and J. E. Varner. 1954. Peptide bond synthesis in higher plants. II. Studies on the mechanism of synthesis of $\gamma$-glutamylcysteine. Arch. Biochem. Biophys. 52: 22.

16. Orlowski, M., and A. Meister. 1971. Isolation of highly purified $\gamma$-glutamylcysteine synthetase from rat kidney. Biochemistry. 10: 372 . 